\title{
Programmed cell death-ligand 1 expression predicts survival in patients with gastric carcinoma with microsatellite instability
}

\author{
Junhun $\mathrm{Cho}^{1}$, Jeeyun Lee ${ }^{2}$, Heejin Bang ${ }^{3}$, Seung Tae Kim², Se Hoon Park ${ }^{2}$, Ji Yeong \\ $\mathrm{An}^{4}$, Min Gew Choi ${ }^{4}$, Joon Ho Lee ${ }^{4}$, Tae Sung Sohn ${ }^{4}$, Jae Moon Bae ${ }^{4}$, Won Ki Kang ${ }^{2}$, \\ Sung Kim4, Kyoung-Mee Kim ${ }^{3}$ \\ ${ }^{1}$ Department of Pathology, Soonchunhyang University Cheonan Hospital, Soonchunhyang University College of Medicine, \\ Cheonan, Korea \\ ${ }^{2}$ Department of Medicine, Division of Hematology-Oncology, Samsung Medical Center, Sungkyunkwan University School of \\ Medicine, Seoul, Korea \\ ${ }^{3}$ Department of Pathology and Translational Genomics, Samsung Medical Center, Sungkyunkwan University School of Medicine, \\ Seoul, Korea \\ ${ }^{4}$ Department of Surgery, Samsung Medical Center, Sungkyunkwan University School of Medicine, Seoul, Korea
}

Correspondence to: Kyoung-Mee Kim, email: kkmkys@skku.edu

Keywords: programmed death-ligand 1, gastric cancer, prognosis, immune, therapy

Received: October 15, $2016 \quad$ Accepted: December 27, $2016 \quad$ Published: January 05, 2017

\section{ABSTRACT}

Programmed death-ligand 1 (PD-L1) is expressed in a subgroup of gastric cancers that may benefit from immunotherapy. Microsatellite instability-high (MSI-H) is a potential predictive factor for response to immunotherapy targeting the PD-1 or its ligand PD-L1. The relationship between PD-L1 expression and MSI-H status remains poorly understood. In this study, we investigated PD-L1 expression in patients with MSI-H gastric cancer. We analyzed PD-L1 expression in 78 MSI-H gastric cancer tissue samples using immunohistochemistry. PD-L1 expression was classified as expression on tumor cells or on immune cells. We observed PD-L1 expression in 48 gastric cancer samples $(61.5 \%)$, consisting of $7(9.0 \%)$ cases with tumor PD-L1 expression and $47(60.3 \%)$ cases with immune cell PD-L1 expression. Immune cell PD-L1 expression was frequently associated with intestinal type cancer by the Lauren classification $(p=0.015)$, with a lower risk of lymph node metastasis $(p=0.027)$ and lower tumor stages $(p=0.029)$ compared to MSI-H gastric cancers without PD-L1 expression. Moreover, immune cell PD-L1 expression was an independent favorable prognostic factor for overall survival (versus PD-L1 negative; hazard ratio, 3.451; 95\% confidence interval, 1.172-12.745; $p=0.025$ ). In MSI-H gastric cancer, PD-L1 expression was observed to be independently associated with a longer survival.

\section{INTRODUCTION}

Gastric cancer is the fourth most commonly diagnosed cancer and the second leading cause of cancerrelated mortality worldwide [1]. The most effective treatment for localized gastric carcinoma is curative resection; however, approximately half of all patients with advanced-stage disease experience recurrence following surgery. The postoperative prognosis of patients with advanced gastric carcinoma remains poor $[2,3]$.

The Cancer Genome Atlas (TCGA) research network proposed a molecular classification dividing gastric carcinoma into four subtypes. One of them, microsatellite instability-high (MSI-H) tumors, is associated with elevated mutation rates including mutations in genes encoding targetable oncogenic signaling proteins [4]. The rate of incidence of MSI-H status in gastric carcinoma was previously reported to be $8.5 \%-37.8 \%$ [5]. However, the prognostic significance of MSI-H status in gastric carcinoma has been controversial [6-11]. Recently, a hypothesis has been proposed that cancers with a high prevalence of somatic mutations due to mismatch-repair defects may be susceptible to immune checkpoint blockade [12]. A phase 2 clinical trial for evaluating the clinical activity of pembrolizumab, the first programmed death 1 (PD-1) inhibitor, revealed that patients with MSI-H 
colorectal carcinomas and high somatic mutation loads are associated with better prognosis than patients with microsatellite stable (MSS) cancer [13]. Programmed death receptor-ligand 1 (PD-L1; also known as B7-H1 or CD274) is known to play an important role in immune evasion of tumor cells. PD-L1 on tumor cells interacts with PD-1 on $\mathrm{T}$ cells and decreases $\mathrm{T}$ cell receptor (TCR)-mediated proliferation and cytokine production [14]. Therefore, the inhibition of PD-1/PD-L1 interactions might improve the efficacy of adoptive cell therapy for malignancies. Previous studies have shown that the expression of PD-L1 is linked with a worse prognosis in patients with cancer compared with those without PD-L1 expression; however, this finding remains controversial in case of some cancers [15]. Multiple studies on gastric carcinoma utilizing immunohistochemistry (IHC) for PD-L1 demonstrated varying rates of PD-L1 expression, ranging from 5.1\% to $65.0 \%$ [16-26]. In the majority of studies, PD-L1 expression was associated with an unfavorable prognosis [16-22, 25, 26]; however, recent studies have linked PD-L1 expression with a favorable prognosis [23, 24].

Although the relationship between MSI-H gastric carcinoma and PD-L1 status has not been fully explored, we hypothesized that a therapeutic strategy targeting the PD-1/PD-L1 interactions may be more effective in patients with MSI-H gastric carcinoma than in those with MSS gastric carcinoma. Accordingly, the connection between MSI-H status and PD-L1 expression in patients with gastric carcinoma requires investigation. In the present study, we investigated the clinicopathological characteristics of PD-L1 expression in patients with MSI-H gastric carcinoma and found that PD-L1 expression was an independent prognostic factor for the survival of such patients.

\section{RESULTS}

\section{Patient characteristics and PD-L1 expression}

The mean age of the patients with gastric carcinoma was 65.9 (range, 31-88). The male-to-female ratio was 1.6:1. The mean follow-up period was $56.9 \pm 26.1$ months. Eighteen (23.1\%) patients experienced a recurrence, and $16(20.5 \%)$ patients died of the disease. Of the 78 gastric cancer cases, $15(19.2 \%)$ were diagnosed as stage I, $30(38.5 \%)$ as stage II, $23(29.5 \%)$ as stage III, and 10 $(12.8 \%)$ as stage IV. All patients were Epstein-Barr virus (EBV)-negative.

Prominent staining of PD-L1 was observed at the periphery of the tumor, i.e., the infiltrating front (Figure 1). Seven cases (9.0\%) and 47 cases (60.3\%) were classified into the groups showing PD-L1 expression in tumor cells (PD-L1 ${ }^{\mathrm{TC}+}$ ) and in immune cells (PD-L1 ${ }^{\mathrm{IC}+}$ ), respectively. Six of 7 patients with $\mathrm{PD}-\mathrm{L}^{\mathrm{TC}+}$ status were also positive for PD-L1 ${ }^{\mathrm{IC}+}$ status. Table 1 summarizes the clinicopathological findings based on PD-L1 expression status. In MSI-H gastric carcinoma, PD-L1 ${ }^{\mathrm{IC}+}$ status was more frequently observed in intestinal type tumors $(p=0.015)$, as well as in those with a lower risk of lymph node metastasis $(p=0.027)$ and lower tumor, node, and metastasis (TNM) classification stages compared to $\mathrm{PD}-\mathrm{L} 1^{\mathrm{IC}-}$ group $(p=0.029)$. However, there was no significant association between $\mathrm{PD}-\mathrm{L}^{\mathrm{TC}+}$ status and histological type of the tumor by the Lauren classification, $\mathrm{pN}$ status, or the TNM stage classification. Age, sex, location, and pT status demonstrated no significant correlation with PD-L1 IHC in either tumor cells or immune cells.

\section{PD-L1 expression and prognosis}

The mean disease-free survival (DFS) and overall survival (OS) of patients with $\mathrm{PD}-\mathrm{L} 1^{\mathrm{IC}+}$ gastric carcinoma was higher than that of patients with PD- L1 ${ }^{\mathrm{IC}-}$ gastric carcinoma (44.4 and 62.2 months vs. 33.9 and 48.7 months, respectively). PD-L1 ${ }^{\mathrm{IC}+}$ status was significantly associated with a longer OS (log rank $p=0.011$ ) but not with a longer DFS (Figure 2). PD-L1 expression in tumor cells showed a trend towards a better prognosis; however, it was not significantly related to DFS or OS. All seven PD-L1 ${ }^{\mathrm{TC}+}$ patients are alive without disease recurrence during the follow-up period (mean OS, 55.7 months). Two of them were TNM stage II and five of them had TNM stage III disease. Of nine TNM stage IV patients, six patients died after recurrence and they were all PD-L1 negative. Other three patients survived without disease progression were unexceptionally PD-L1 $1^{\mathrm{IC}+}$ and their DFS were 63.8, 68.4, and 69.6 months, respectively. In multivariate analysis, the PD-L1 ${ }^{\mathrm{IC}-}$ group showed a significantly shorter OS $(95 \%$ confidence intervals, 1.172-10.162; hazard ratio, 3.451) when compared with the PD-L1 ${ }^{\mathrm{IC}+}$ group (Table 2).

\section{DISCUSSION}

Recently, anti-PD-1/PD-L1 antibodies have shown remarkable therapeutic effects in advanced solid cancers. However, the interaction between PD-L1 expression and MSI remains poorly understood. We investigated PD-L1 expression in patients with MSI-H gastric carcinoma and observed that PD-L1 was expressed in $61.5 \%$ of tumors and that it was an independent favorable prognostic factor for survival.

To establish an anti-PD-1/PD-L1 therapeutic strategy, it is important to explore the relationship between MSI-H gastric carcinoma and PD-L1 expression. Previous studies revealed an adverse prognostic effect of PD-L1 expression in various cancers [27-35]. However, several recent studies have reported that a higher PD-L1 expression is associated with an increased number of tumor-infiltrating lymphocytes (TILs) and a longer survival in metastatic melanoma [18], Merkel cell carcinoma [36], non-small cell lung cancer $[37,38]$, 
Table 1: Demographic distribution and clinicopathological features in microsatellite instabilityhigh gastric cancer

\begin{tabular}{|c|c|c|c|c|c|c|c|c|c|c|c|c|}
\hline & & \multirow{3}{*}{ Total } & \multicolumn{5}{|c|}{ Tumor cells } & \multicolumn{5}{|c|}{ Immune cells } \\
\hline & & & \multirow{2}{*}{\multicolumn{2}{|c|}{$\frac{\text { Negative }}{\text { Number }(\%)}$}} & \multirow{2}{*}{\multicolumn{2}{|c|}{$\frac{\text { Positive }}{\text { Number (\%) }}$}} & \multirow{2}{*}{$p$ value } & \multirow{2}{*}{\multicolumn{2}{|c|}{$\frac{\text { Negative }}{\text { Number (\%) }}$}} & \multirow{2}{*}{\multicolumn{2}{|c|}{$\begin{array}{c}\text { Positive } \\
\text { Number }(\%)\end{array}$}} & \multirow{2}{*}{$p$ value } \\
\hline & & & & & & & & & & & & \\
\hline \multirow[t]{2}{*}{ Age } & $<60$ & 19 & 19 & $(100.0)$ & 0 & $(0.0)$ & 0.129 & 8 & $(42.1)$ & 11 & $(57.9)$ & 0.507 \\
\hline & $\geq 60$ & 59 & 52 & $(88.1)$ & 7 & (11.9) & & 23 & $(39.0)$ & 36 & $(61.0)$ & \\
\hline \multirow[t]{2}{*}{ Sex } & Male & 48 & 43 & $(89.6)$ & 5 & $(10.4)$ & 0.449 & 20 & $(41.7)$ & 28 & $(58.3)$ & 0.422 \\
\hline & Female & 30 & 28 & $(93.3)$ & 2 & $(6.7)$ & & 11 & $(36.7)$ & 19 & $(63.3)$ & \\
\hline \multirow[t]{4}{*}{ Location } & Cardia & 3 & 2 & $(66.7)$ & 1 & $(33.3)$ & 0.437 & 1 & (33.3) & 2 & $(66.7)$ & 0.270 \\
\hline & Body & 16 & 15 & $(93.8)$ & 1 & $(6.3)$ & & 3 & $(18.8)$ & 13 & $(81.3)$ & \\
\hline & Antrum & 55 & 50 & $(90.9)$ & 5 & $(9.1)$ & & 25 & $(45.5)$ & 30 & $(54.5)$ & \\
\hline & $\begin{array}{l}\text { Multiple/ } \\
\text { Whole }\end{array}$ & 4 & 4 & $(100.0)$ & 0 & $(0.0)$ & & 2 & $(50.0)$ & 2 & $(50.0)$ & \\
\hline \multirow[t]{3}{*}{ Lauren type } & Intestinal & 48 & 44 & $(91.7)$ & 4 & (8.3) & 0.671 & 16 & $(33.3)$ & 32 & $(66.7)$ & 0.015 \\
\hline & Diffuse & 25 & 23 & $(92.0)$ & 2 & $(8.0)$ & & 15 & $(60.0)$ & 10 & $(40.0)$ & \\
\hline & Mixed & 5 & 4 & $(80.0)$ & 1 & $(20.0)$ & & 0 & $(0.0)$ & 5 & $(100.0)$ & \\
\hline \multirow[t]{2}{*}{ EBV } & Negative & 78 & 71 & $(91.0)$ & 7 & $(9.0)$ & & 31 & (39.7) & 47 & $(60.3)$ & \\
\hline & Positive & 0 & 0 & & 0 & & & 0 & & 0 & & \\
\hline \multirow[t]{4}{*}{ pT status } & pT1 & 1 & 1 & (100.0) & 0 & $(0.0)$ & 0.595 & 0 & $(0.0)$ & 1 & $(100.0)$ & 0.054 \\
\hline & pT2 & 45 & 42 & $(93.3)$ & 3 & $(6.7)$ & & 14 & (31.1) & 31 & (68.9) & \\
\hline & pT3 & 19 & 16 & $(84.2)$ & 3 & $(15.8)$ & & 10 & $(52.6)$ & 9 & $(47.4)$ & \\
\hline & pT4 & 13 & 12 & $(92.3)$ & 1 & $(7.7)$ & & 7 & $(53.8)$ & 6 & $(46.2)$ & \\
\hline \multirow[t]{4}{*}{$\mathrm{pN}$ status } & $\mathrm{pN} 0$ & 16 & 15 & $(93.8)$ & 1 & (6.3) & 0.562 & 2 & $(12.5)$ & 14 & $(87.5)$ & 0.027 \\
\hline & $\mathrm{pN} 1$ & 34 & 32 & $(94.1)$ & 2 & (5.9) & & 15 & $(44.1)$ & 19 & $(55.9)$ & \\
\hline & $\mathrm{pN} 2$ & 21 & 17 & $(81.0)$ & 4 & (19.0) & & 10 & $(47.6)$ & 11 & $(52.4)$ & \\
\hline & $\mathrm{pN} 3$ & 7 & 7 & $(100.0)$ & 0 & $(0.0)$ & & 4 & $(57.1)$ & 3 & $(42.9)$ & \\
\hline \multirow[t]{4}{*}{ TNM stage } & I & 15 & 15 & (100.0) & 0 & $(0.0)$ & 0.313 & 2 & $(13.3)$ & 13 & $(86.7)$ & 0.037 \\
\hline & II & 30 & 27 & $(90.0)$ & 3 & $(10.0)$ & & 13 & $(43.3)$ & 17 & $(56.7)$ & \\
\hline & III & 23 & 19 & $(82.6)$ & 4 & (17.4) & & 10 & $(43.5)$ & 13 & $(56.5)$ & \\
\hline & IV & 10 & 10 & $(100.0)$ & 0 & $(0.0)$ & & 6 & $(60.0)$ & 4 & $(40.0)$ & \\
\hline
\end{tabular}

Abbreviations: EBV, Epstein-Barr virus.

and breast cancer [39]. In gastric carcinoma, patients with PD-L1-positive cancer showed significantly shorter survivals compared with those with PD-L1 negative cancer [16-22, 25, 26]. However, recent studies have found PD-L1 expression to be a favorable prognostic marker in gastric cancer $[23,24]$. In the present study with MSI-H gastric carcinomas, we observed PD-L1 ${ }^{\mathrm{TC}+}$ in $9.0 \%$ of cases and $\mathrm{PD}-\mathrm{L} 1^{\mathrm{IC}+}$ in $60.3 \%$ of cases. The positive rate of PD-L1 in tumor cells $(9.0 \%)$ is generally lower than previous studies on gastric cancers (5.1\% to $65.0 \%)$ [16-26]. It can be caused by the used primary antibody and diagnostic criteria of PD-L1 expression. Out of 11 previous studies, only one study used the same antibody as ours (clone SP142; Ventana, Tucson, AZ). In that study[26], PD-L1 positive GC was $40.9 \%$ (56/137): the criterion of PD-L1 positivity was $5 \%$ in tumor cells and their study consists many EBVpositive gastric carcinomas with lymphoid stroma, which are strongly associated with PD-L1 expression in tumor cells.

Unexpectedly, intra- or peritumoral immune cells with PD-L1 expression was associated with a longer OS. 
Table 2: Multivariate analysis of death in all 78 patients with microsatellite instability-high gastric cancer

\begin{tabular}{llccc}
\hline & & HR & 95\% CI & $p$ value \\
\hline PD-L1 in IC & & & \\
& PD-L1 ${ }^{\mathrm{IC}+}$ & ref & & \\
& PD-L1 $^{\mathrm{IC}-}$ & 3.451 & $1.172-12.745$ & \\
& & & 0.030 \\
TNM stage & & & \\
& I & ref & & \\
& II & 1.384 & $0.150-12.745$ & \\
& III & 2.597 & $0.293-23.020$ & \\
& IV & 7.857 & $0.905-68.218$ & \\
\hline
\end{tabular}

Abbreviations: HR, hazard ratio; CI, confidence interval.

All 7 patients with PD-L1 ${ }^{\mathrm{TC}+}$ status survived and none experienced recurrence during their long (mean: 55.7 months) follow-up period, which was interrupted to achieve statistical significance. Moreover, PD-L1 expression in TILs was observed in $85.7 \%$ of patients with a PD-L1 ${ }^{\mathrm{TC}+}$ status. This finding suggested that the expression of PD-L1 in tumor cells and intra- and peritumoral immune cells is closely related. Moreover, the release of interferon gamma (IFN- $\gamma$ ) by TILs can directly induce PD-L1 expression in tumor cells and immune cells [40-42].

Patients with gastric carcinoma and high TIL levels have been reported to have a favorable prognosis $[7,13,43]$. It has been reported that PD-1/PD-L1 interaction inhibits $\mathrm{T}$ lymphocyte proliferation, survival, and effector functions; promotes the differentiation of CD4+ $\mathrm{T}$ cells into Foxp3+ regulatory $\mathrm{T}$ (Treg) cells; and increases the resistance of tumor cells to cytotoxic T lymphocyte attacks [44]. However, we found a longer OS in patients with MSI-H gastric carcinoma with
PD-L1 expression, an observation that was contradictory to the previous theory. However, the present results are consistent with our recent report that a higher number of Tregs among CD4+ T cells correlated with increased OS and DFS and it was an independent prognostic factor for gastric carcinoma [45]. PD-L1 expression in tumors can be driven either by constitutive oncogene activation or by inflammation-mediated immune attack [46]. According to the cancer immunoediting hypothesis [47], newly developing tumor cells are detected and destroyed by the innate and adaptive immune systems, the socalled "elimination phase". Following this, tumor cells that survive the elimination phase enter the equilibrium phase. In this process, some tumor cells can acquire the ability to overcome the host antitumor immunity. One of the consequences of this process is PD-L1 upregulation. PD-L1 expression in tumor cells signifies not only immune evasion of the tumor, but also the preexistence of a robust antitumor immune attack. Immunoedited

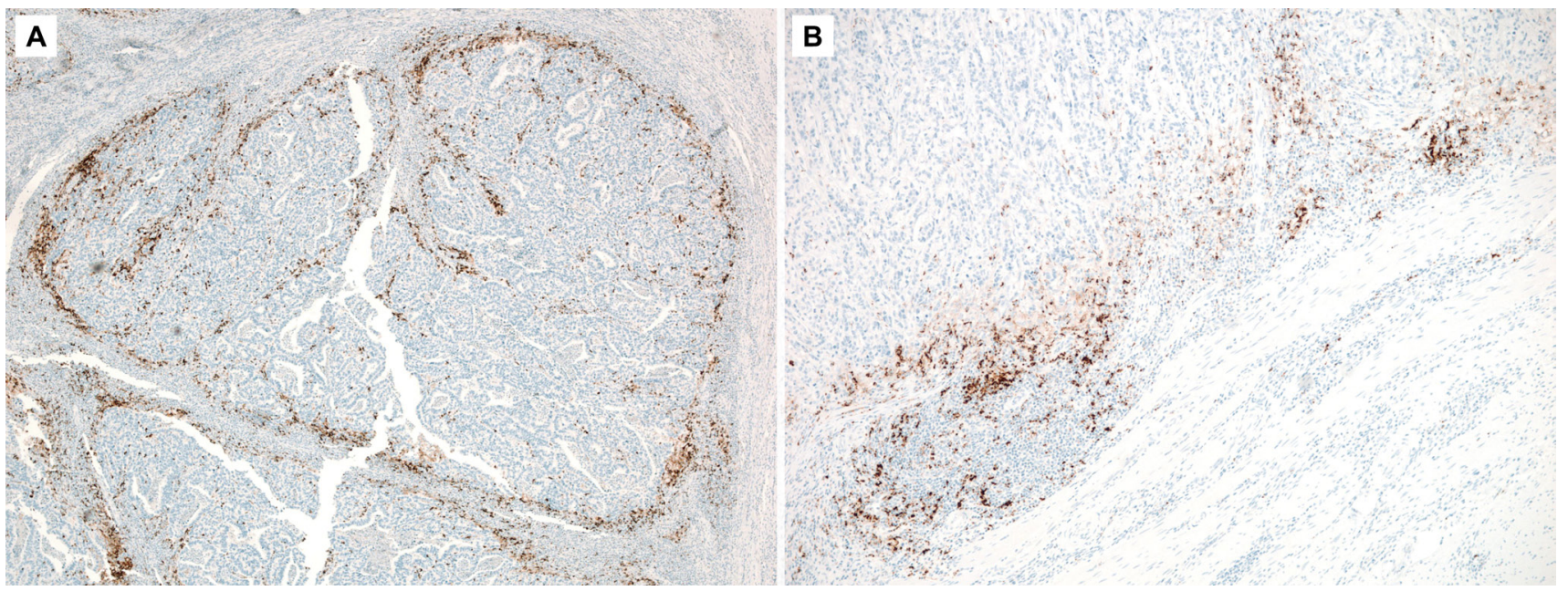

Figure 1: A representative photomicrograph of PD-L1 immunohistochemistry showing high staining in the deeply invasive front of the tumor. 
PD-L1-positive tumor cells cannot enter the escape phase and remain in the equilibrium phase; thus, the patient might experience a relatively indolent clinical course. This process is extremely complex and delicate, meaning that minimal diversity in genetic, racial, and environmental features of patients can result in various clinical outcomes. Taken together, the exact roles of PD-L1 in malignant tumors and anti-PD-1/ PD-L1 antibodies in immunotherapy in patients with different cancers have not been well established yet. However, we assume that PD-L1 in gastric carcinoma may also have antitumorigenic properties through the fostering of particular immune reactions; the precise underlying mechanisms for the same will need to be elucidated in the near future.

Recent studies with a few MSI-H gastric carcinoma cases (indicated via IHC of mismatch repair proteins) demonstrated significantly higher rates of PD-L1 expression compared to MSS gastric carcinoma [24, 26, $48,49]$. Therefore, we studied a large number of MSI-H gastric cancers and the current research without direct comparison with MSS gastric cancers could be a limitation of the present study and warrants further study.
In a phase $1 \mathrm{~b}$ clinical trial (KEYNOTE-012 study) conducted to assess pembrolizumab, 8 out of 36 patients $(22.2 \%)$ with PD-L1-positive gastric carcinoma or gastroesophageal junction cancer were judged to have a partial response. Among 4 patients with MSI-H gastric carcinoma, 2 had a partial response and the other 2 had progressive disease [50]. One of the noteworthy findings of this trial is that the response rate for pembrolizumab was higher in the low PD-L1 tumor proportion score group and the high PD-L1 mononuclear inflammatory cell density score group than in the groups that had high and low scores, respectively, on these measures. These results support our findings that the expression of PD-L1 not only in tumor cells, but also in immune cells, is important in the antitumor microenvironment.

In summary, PD-L1 expression, especially in intraand peritumoral immune cells, is related to longer survival in patients with MSI-H gastric carcinoma. Further studies are necessary to elucidate the underlying immunological pathways and to predict which gastric carcinoma subclass may respond most favorably to anti-PD-1/PD-L1 immunotherapy.

Tumor cells
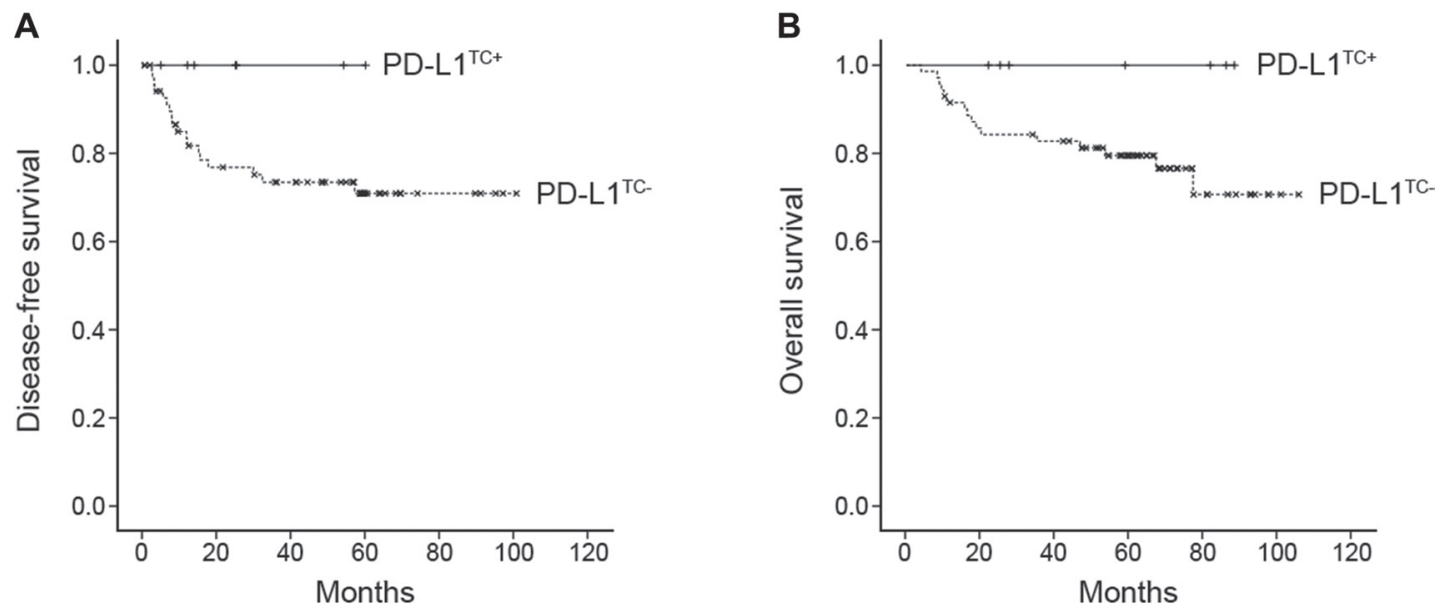

Immune cells
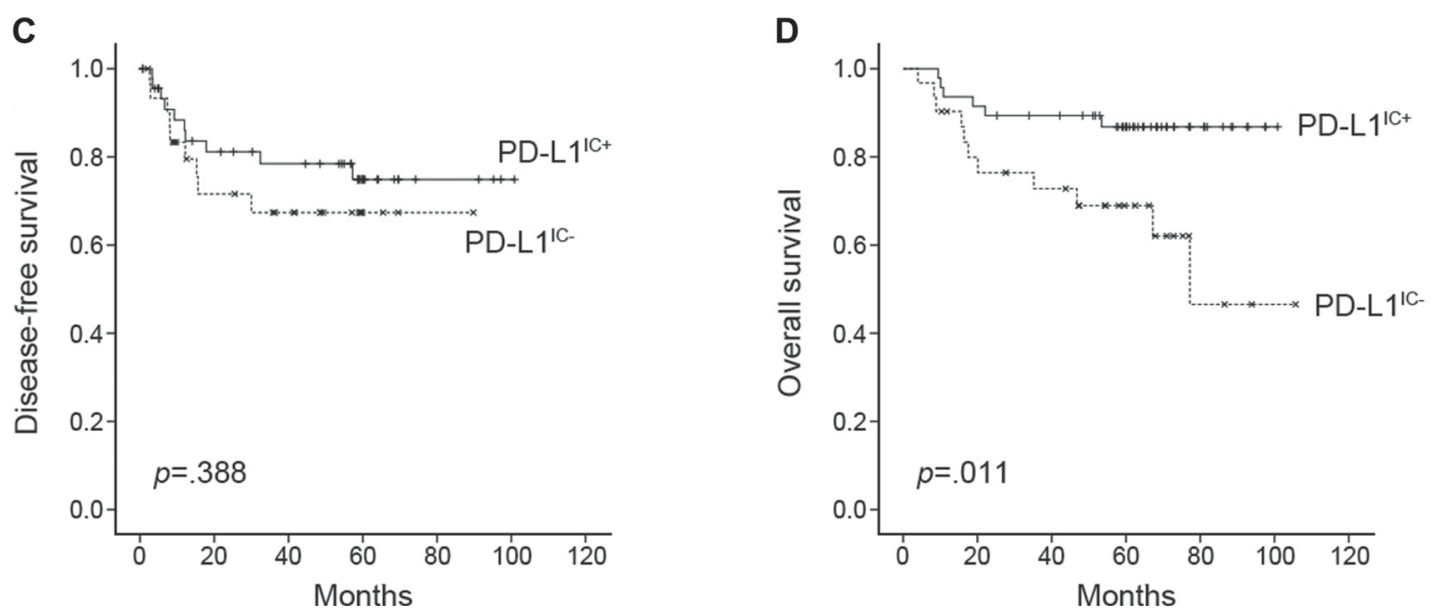

Figure 2: Kaplan-Meier survival curves of disease-free survival and overall survival according to PD-L1 expression in tumor cells (A, B) and immune cells $(\mathbf{C}, \mathbf{D})$. No statistics were computed in A and B because all PD-L1 ${ }^{\mathrm{TC}+}(n=7)$ cases were censored. 


\section{MATERIALS AND METHODS}

\section{Patient selection}

Patients who underwent surgery for primary gastric carcinoma from September 2004 to September 2011 at Samsung Medical Center were eligible for this study. Among them, 78 patients with MSI-H tumors were selected from our previous study cohort of 620 patients including $58(85 \%)$ cases from $68 \mathrm{MSI}-\mathrm{H}$ gastric cancers [15], $6(100 \%)$ cases from ARTIST cohort [51] and 14 (100\%) from SMC DASL study cohort [52].

All 78 patients underwent radical gastrectomy with D2 lymph node dissection with or without adjuvant chemoradiation therapy (INT-0116 regimen) [53]. No patient had any other uncontrolled cancer at the time of diagnosis of gastric carcinoma or during the follow-up period. Clinical data including demographic features, tumor characteristics, and treatment outcomes were obtained by reviewing medical records using the intranet resources of Samsung Medical Center. Tumor stage was defined according to the TNM classification described in the 7th edition of the AJCC cancer staging manual [54]. All patients provided informed consent according to our institutional guidelines.

\section{Microsatellite instability}

For MSI analysis, we performed multiplex polymerase chain reaction (PCR) with five quasi-monomorphic mononucleotide repeat markers as previously described [55]. Briefly, genomic DNA was isolated from formalin-fixed, paraffin-embedded (FFPE) tumor samples with a QIAamp DNA mini kit (Qiagen, Valencia, CA, USA). Each sense primer was end-labeled with one of the fluorescent markers
FAM, HEX, or NED. Amplified PCR products were run on an ABI Prism 3130 Genetic Analyzer (Applied Biosystems, Foster City, CA, USA). Allelic sizes were estimated by Genemapper 4.1 (Applied Biosystems), and samples with no allelic size variations in fewer than two of the microsatellites were classified as MSS. Tumors with allelic size variations in two or more of the microsatellite markers were considered MSI-H.

\section{EBV-encoded RNA in situ hybridization}

Three-micrometer-thick sections were cut from each tissue block and mounted on Superfrost-plus slides (Thermo Scientific, Waltham, MA, USA). We performed in situ hybridization with BOND-MAX with an EBVencoded RNA probe (Leica, Newcastle, UK). Only sections that showed a strong signal within almost all tumor cell nuclei were considered positive.

\section{Immunohistochemistry}

We performed IHC on all $78 \mathrm{MSI}-\mathrm{H}$ gastric carcinoma samples. Staining for PD-L1 in FFPE tissue sections was conducted using a rabbit anti-human PD-L1 monoclonal antibody (clone SP142; Ventana, Tucson, AZ). The percentages of tumor cells and peritumoral immune cells that stained positive for PD-L1 were analyzed independently by two pathologists (J.C. and K.M.K.). A tumor was considered positive for PD-L1 if there was histological evidence of cytoplasmic and/or membranous staining. Percentages of PD-L1 positive tumor cells were quantified as $1 \%, 2 \%, 3$ to $5 \%, 6$ to $10 \%$, and then in $10 \%$ increments up to $100 \%$ and the samples were given a score of $0,1+, 2+$, or $3+$ based on the intensity of staining (Figure 3). Based on our preliminary statistical analyses

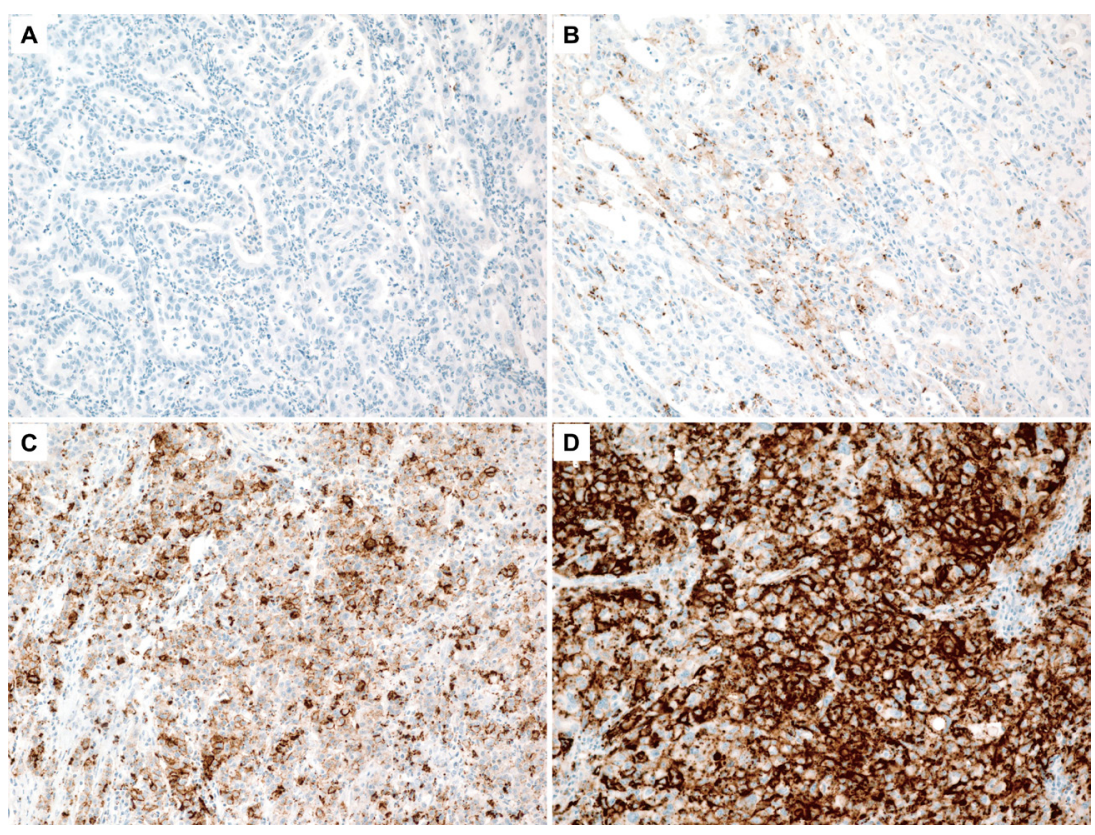

Figure 3: A tumor was scored as $0(\mathbf{A}), 1+(\mathbf{B}), 2+(\mathbf{C})$, or $3+(\mathbf{D})$ based on the intensity of cytoplasmic and/or membranous staining in $>10 \%$ of tumor cells. 
and previous publication on solid cancers [56], scores of $2+$ and $3+$, and $>10 \%$ were defined as the criteria of PD-L1 ${ }^{\mathrm{TC}+}$. For peritumoral immune cells a score of 0,1 , 2 , or 3 was given when $<1 \%$; $\geq 1 \%$ but $<5 \%$; $\geq 5 \%$ but $<10 \%$; or $\geq 10 \%$ of cells per area were PD-L1-positive, respectively, as previously described [57]. Scores of 2 and 3 were classified as PD-L1 ${ }^{\mathrm{IC}+}$. To reduce interobserver variation, all the cases were reviewed by two pathologists, and in cases with disagreement, the final interpretation was determined by consensus using the multi-head microscope.

\section{Prognostic model building and statistical analysis}

We analyzed the clinicopathological characteristics such as age, sex, pTNM stage (AJCC 7th edition), DFS, and OS of patients. For statistical analyses, we used SPSS 18.0 statistical software program (SPSS Inc., Chicago, IL, USA). We compared PD-L1 expression and clinicopathological variables with Pearson's chisquare test and the chi-square test using linear-bylinear association. We used the Kaplan-Meier method to estimate DFS and OS. To evaluate the association between clinicopathological factors and survival, the Cox proportional hazard model was used. $p$-values less than 0.05 were considered statistically significant.

\section{ACKNOWLEDGMENTS AND FUNDING}

This work was supported by a grant from the Korean Health Technology R\&D Project, Ministry of Health \& Welfare, Republic of Korea (HI14C3418, HI16C1990) and the 20 by 20 project of Samsung Medical Center (GF01140111).

\section{CONFLICTS OF INTEREST}

None.

\section{REFERENCES}

1. Kelley JR, Duggan JM. Gastric cancer epidemiology and risk factors. J Clin Epidemiol. 2003; 56:1-9.

2. Wu CW, Lo SS, Shen KH, Hsieh MC, Chen JH, Chiang JH, Lin HJ, Li AF, Lui WY. Incidence and factors associated with recurrence patterns after intended curative surgery for gastric cancer. World J Surg. 2003; 27:153-158.

3. Catalano V, Labianca R, Beretta GD, Gatta G, de Braud F, Van Cutsem E. Gastric cancer. Crit Rev Oncol Hematol. 2009; 71:127-164.

4. Blank C, Mackensen A. Contribution of the PD-L1/PD-1 pathway to T-cell exhaustion: an update on implications for chronic infections and tumor evasion. Cancer Immunol Immunother. 2007; 56:739-745.

5. Pyo JS, Kang G, Kim JY. Prognostic role of PD-L1 in malignant solid tumors: a meta-analysis. Int J Biol Markers. 2016:0.
6. dos Santos NR, Seruca R, Constancia M, Seixas M, Sobrinho-Simoes M. Microsatellite instability at multiple loci in gastric carcinoma: clinicopathologic implications and prognosis. Gastroenterology. 1996; 110:38-44.

7. Lee HE, Chae SW, Lee YJ, Kim MA, Lee HS, Lee BL, Kim WH. Prognostic implications of type and density of tumour-infiltrating lymphocytes in gastric cancer. $\mathrm{Br} \mathrm{J}$ Cancer. 2008; 99:1704-1711.

8. Kim H, An JY, Noh SH, Shin SK, Lee YC, Kim H. High microsatellite instability predicts good prognosis in intestinal-type gastric cancers. J Gastroenterol Hepatol. $2011 ; 26: 585-592$.

9. Comprehensive molecular characterization of gastric adenocarcinoma. Nature. 2014; 513:202-209.

10. Choi YY, Bae JM, An JY, Kwon IG, Cho I, Shin HB, Eiji T, Aburahmah M, Kim HI, Cheong JH, Hyung WJ, Noh SH. Is microsatellite instability a prognostic marker in gastric cancer? A systematic review with meta-analysis. J Surg Oncol. 2014; 110:129-135.

11. Llosa NJ, Cruise M, Tam A, Wicks EC, Hechenbleikner EM, Taube JM, Blosser RL, Fan H, Wang H, Luber BS, Zhang M, Papadopoulos N, Kinzler KW, et al. The vigorous immune microenvironment of microsatellite instable colon cancer is balanced by multiple counter-inhibitory checkpoints. Cancer Discov. 2015; 5:43-51.

12. Marrelli D, Polom K, Pascale V, Vindigni C, Piagnerelli R, De Franco L, Ferrara F, Roviello G, Garosi L, Petrioli R, Roviello F. Strong Prognostic Value of Microsatellite Instability in Intestinal Type Non-cardia Gastric Cancer. Ann Surg Oncol. 2016; 23:943-950.

13. Song HJ, Srivastava A, Lee J, Kim YS, Kim KM, Ki Kang W, Kim M, Kim S, Park CK, Kim S. Host inflammatory response predicts survival of patients with Epstein-Barr virus-associated gastric carcinoma. Gastroenterology. 2010; 139:84-92.e82.

14. An JY, Kim H, Cheong JH, Hyung WJ, Kim H, Noh SH. Microsatellite instability in sporadic gastric cancer: its prognostic role and guidance for 5-FU based chemotherapy after R0 resection. Int J Cancer. 2012; 131:505-511.

15. Cristescu R, Lee J, Nebozhyn M, Kim KM, Ting JC, Wong SS, Liu J, Yue YG, Wang J, Yu K, Ye XS, Do IG, Liu S, et al. Molecular analysis of gastric cancer identifies subtypes associated with distinct clinical outcomes. Nat Med. 2015; 21:449-456.

16. Wu C, Zhu Y, Jiang J, Zhao J, Zhang XG, Xu N. Immunohistochemical localization of programmed death-1 ligand-1 (PD-L1) in gastric carcinoma and its clinical significance. Acta Histochem. 2006; 108:19-24.

17. Sun J, Xu K, Wu C, Wang Y, Hu Y, Zhu Y, Chen Y, Shi Q, Yu G, Zhang X. PD-L1 expression analysis in gastric carcinoma tissue and blocking of tumor-associated PD-L1 signaling by two functional monoclonal antibodies. Tissue Antigens. 2007; 69:19-27.

18. Taube JM, Anders RA, Young GD, Xu H, Sharma R, McMiller TL, Chen S, Klein AP, Pardoll DM, Topalian SL, 
Chen L. Colocalization of inflammatory response with B7-h1 expression in human melanocytic lesions supports an adaptive resistance mechanism of immune escape. Sci Transl Med. 2012; 4:127ra137.

19. Hou J, Yu Z, Xiang R, Li C, Wang L, Chen S, Li Q, Chen M, Wang L. Correlation between infiltration of FOXP3+ regulatory $\mathrm{T}$ cells and expression of $\mathrm{B} 7-\mathrm{H} 1$ in the tumor tissues of gastric cancer. Exp Mol Pathol. 2014; 96:284-291.

20. Qing Y, Li Q, Ren T, Xia W, Peng Y, Liu GL, Luo H, Yang YX, Dai XY, Zhou SF, Wang D. Upregulation of PD-L1 and APE1 is associated with tumorigenesis and poor prognosis of gastric cancer. Drug Des Devel Ther. 2015; 9:901-909.

21. Geng Y, Wang H, Lu C, Li Q, Xu B, Jiang J, Wu C. Expression of costimulatory molecules B7-H1, B7-H4 and Foxp3+ Tregs in gastric cancer and its clinical significance. Int J Clin Oncol. 2015; 20:273-281.

22. Eto S, Yoshikawa K, Nishi M, Higashijima J, Tokunaga T, Nakao T, Kashihara H, Takasu C, Iwata T, Shimada M. Programmed cell death protein 1 expression is an independent prognostic factor in gastric cancer after curative resection. Gastric Cancer. 2016; 19:466-471.

23. Kim JW, Nam KH, Ahn SH, Park do J, Kim HH, Kim SH, Chang H, Lee JO, Kim YJ, Lee HS, Kim JH, Bang SM, Lee JS, et al. Prognostic implications of immunosuppressive protein expression in tumors as well as immune cell infiltration within the tumor microenvironment in gastric cancer. Gastric Cancer. 2016; 19:42-52.

24. Boger C, Behrens HM, Mathiak M, Kruger S, Kalthoff H, Rocken C. PD-L1 is an independent prognostic predictor in gastric cancer of Western patients. Oncotarget. 2016; 7:24269-24283. doi: 10.18632/oncotarget.8169.

25. Schlosser HA, Drebber U, Kloth M, Thelen M, Rothschild SI, Haase S, Garcia-Marquez M, Wennhold K, Berlth F, Urbanski A, Alakus H, Schauss A, Shimabukuro-Vornhagen A, et al. Immune checkpoints programmed death 1 ligand 1 and cytotoxic T lymphocyte associated molecule 4 in gastric adenocarcinoma. Oncoimmunology. 2016; 5:e1100789.

26. Li Z, Lai Y, Sun L, Zhang X, Liu R, Feng G, Zhou L, Jia L, Huang X, Kang Q, Lin D, Gao J, Shen L. PD-L1 expression is associated with massive lymphocyte infiltration and histology in gastric cancer. Hum Pathol. 2016; 55:182-189.

27. Ohigashi Y, Sho M, Yamada Y, Tsurui Y, Hamada K, Ikeda N, Mizuno T, Yoriki R, Kashizuka H, Yane K, Tsushima F, Otsuki N, Yagita H, et al. Clinical significance of programmed death-1 ligand-1 and programmed death-1 ligand-2 expression in human esophageal cancer. Clin Cancer Res. 2005; 11:2947-2953.

28. Thompson RH, Kuntz SM, Leibovich BC, Dong H, Lohse CM, Webster WS, Sengupta S, Frank I, Parker AS, Zincke H, Blute ML, Sebo TJ, Cheville JC, et al. Tumor $\mathrm{B} 7-\mathrm{H} 1$ is associated with poor prognosis in renal cell carcinoma patients with long-term follow-up. Cancer Res. 2006; 66:3381-3385.
29. Nakanishi J, Wada Y, Matsumoto K, Azuma M, Kikuchi K, Ueda S. Overexpression of B7-H1 (PD-L1) significantly associates with tumor grade and postoperative prognosis in human urothelial cancers. Cancer Immunol Immunother. 2007; 56:1173-1182.

30. Nomi T, Sho M, Akahori $T$, Hamada K, Kubo A, Kanehiro H, Nakamura S, Enomoto K, Yagita H, Azuma M, Nakajima Y. Clinical significance and therapeutic potential of the programmed death-1 ligand/programmed death-1 pathway in human pancreatic cancer. Clin Cancer Res. 2007; 13:2151-2157.

31. Hamanishi J, Mandai M, Iwasaki M, Okazaki T, Tanaka Y, Yamaguchi K, Higuchi T, Yagi H, Takakura K, Minato N, Honjo T, Fujii S. Programmed cell death 1 ligand 1 and tumor-infiltrating $\mathrm{CD} 8+\mathrm{T}$ lymphocytes are prognostic factors of human ovarian cancer. Proc Natl Acad Sci USA. 2007; 104:3360-3365.

32. Hino R, Kabashima K, Kato Y, Yagi H, Nakamura M, Honjo T, Okazaki T, Tokura Y. Tumor cell expression of programmed cell death-1 ligand 1 is a prognostic factor for malignant melanoma. Cancer. 2010; 116:1757-1766.

33. Gadiot J, Hooijkaas AI, Kaiser AD, van Tinteren H, van Boven H, Blank C. Overall survival and PD-L1 expression in metastasized malignant melanoma. Cancer. 2011; 117:2192-2201.

34. Zeng Z, Shi F, Zhou L, Zhang MN, Chen Y, Chang XJ, Lu YY, Bai WL, Qu JH, Wang CP, Wang H, Lou M, Wang FS, et al. Upregulation of circulating PD-L1/PD-1 is associated with poor post-cryoablation prognosis in patients with HBV-related hepatocellular carcinoma. PLoS One. 2011; 6:e23621.

35. Wu P, Wu D, Li L, Chai Y, Huang J. PD-L1 and Survival in Solid Tumors: A Meta-Analysis. PLoS One. 2015; 10:e0131403.

36. Lipson EJ, Vincent JG, Loyo M, Kagohara LT, Luber BS, Wang $\mathrm{H}, \mathrm{Xu} \mathrm{H}$, Nayar SK, Wang TS, Sidransky D, Anders RA, Topalian SL, Taube JM. PD-L1 expression in the Merkel cell carcinoma microenvironment: association with inflammation, Merkel cell polyomavirus and overall survival. Cancer Immunol Res. 2013; 1:54-63.

37. Velcheti V, Schalper KA, Carvajal DE, Anagnostou VK, Syrigos KN, Sznol M, Herbst RS, Gettinger SN, Chen L, Rimm DL. Programmed death ligand-1 expression in nonsmall cell lung cancer. Lab Invest. 2014; 94:107-116.

38. Yang $\mathrm{CY}$, Lin MW, Chang YL, Wu CT, Yang PC. Programmed cell death-ligand 1 expression in surgically resected stage I pulmonary adenocarcinoma and its correlation with driver mutations and clinical outcomes. Eur J Cancer. 2014; 50:1361-1369.

39. Schalper KA, Velcheti V, Carvajal D, Wimberly H, Brown J, Pusztai L, Rimm DL. In situ tumor PD-L1 mRNA expression is associated with increased TILs and better outcome in breast carcinomas. Clin Cancer Res. 2014; 20:2773-2782. 
40. Blank C, Brown I, Peterson AC, Spiotto M, Iwai Y, Honjo T, Gajewski TF. PD-L1/B7H-1 inhibits the effector phase of tumor rejection by $\mathrm{T}$ cell receptor (TCR) transgenic CD8+ T cells. Cancer Res. 2004; 64:1140-1145.

41. Chen BJ, Chapuy B, Ouyang J, Sun HH, Roemer MG, $\mathrm{Xu} \mathrm{ML}$, Yu H, Fletcher CD, Freeman GJ, Shipp MA, Rodig SJ. PD-L1 expression is characteristic of a subset of aggressive B-cell lymphomas and virus-associated malignancies. Clin Cancer Res. 2013; 19:3462-3473.

42. Mandai M, Hamanishi J, Abiko K, Matsumura N, Baba T, Konishi I. Dual Faces of IFNgamma in Cancer Progression: A Role of PD-L1 Induction in the Determination of Pro- and Antitumor Immunity. Clin Cancer Res. 2016; 22:2329-2334.

43. Mizukami Y, Kono K, Kawaguchi Y, Akaike H, Kamimura K, Sugai H, Fujii H. Localisation pattern of Foxp3+ regulatory $\mathrm{T}$ cells is associated with clinical behaviour in gastric cancer. Br J Cancer. 2008; 98:148-153.

44. Zitvogel L, Kroemer G. Targeting PD-1/PD-L1 interactions for cancer immunotherapy. Oncoimmunology. 2012; $1: 1223-1225$.

45. Choi HS, Ha SY, Kim HM, Ahn SM, Kang MS, Kim KM, Choi MG, Lee JH, Sohn TS, Bae JM, Kim S, Kang ES. The prognostic effects of tumor infiltrating regulatory $\mathrm{T}$ cells and myeloid derived suppressor cells assessed by multicolor flow cytometry in gastric cancer patients. Oncotarget. 2016; 7:7940-7951. doi: 10.18632/oncotarget.6958.

46. Pardoll DM. The blockade of immune checkpoints in cancer immunotherapy. Nat Rev Cancer. 2012; 12:252-264.

47. Schreiber RD, Old LJ, Smyth MJ. Cancer immunoediting: integrating immunity's roles in cancer suppression and promotion. Science. 2011; 331:1565-1570.

48. Ma C, Patel K, Singhi AD, Ren B, Zhu B, Shaikh F, Sun W. Programmed Death-Ligand 1 Expression Is Common in Gastric Cancer Associated With Epstein-Barr Virus or Microsatellite Instability. Am J Surg Pathol. 2016.

49. Derks S, Liao X, Chiaravalli AM, Xu X, Camargo MC, Solcia E, Sessa F, Fleitas T, Freeman GJ, Rodig SJ, Rabkin CS, Bass AJ. Abundant PD-L1 expression in Epstein-Barr Virus-infected gastric cancers. Oncotarget. 2016; 7:32925-32932. doi: 10.18632/oncotarget.9076.
50. Muro K, Chung HC, Shankaran V, Geva R, Catenacci D, Gupta S, Eder JP, Golan T, Le DT, Burtness B, McRee AJ, Lin CC, Pathiraja K, et al. Pembrolizumab for patients with PD-L1-positive advanced gastric cancer (KEYNOTE-012): a multicentre, open-label, phase $1 \mathrm{~b}$ trial. Lancet Oncol. 2016; 17:717-726.

51. Lee J, Lim DH, Kim S, Park SH, Park JO, Park YS, Lim HY, Choi MG, Sohn TS, Noh JH, Bae JM, Ahn YC, Sohn I, et al. Phase III trial comparing capecitabine plus cisplatin versus capecitabine plus cisplatin with concurrent capecitabine radiotherapy in completely resected gastric cancer with D2 lymph node dissection: the ARTIST trial. J Clin Oncol. 2012; 30:268-273.

52. Lee J, Sohn I, Do IG, Kim KM, Park SH, Park JO, Park YS, Lim HY, Sohn TS, Bae JM, Choi MG, Lim DH, Min BH, et al. Nanostring-based multigene assay to predict recurrence for gastric cancer patients after surgery. PLoS One. 2014; 9:e90133.

53. Macdonald JS, Smalley SR, Benedetti J, Hundahl SA, Estes NC, Stemmermann GN, Haller DG, Ajani JA, Gunderson LL, Jessup JM, Martenson JA. Chemoradiotherapy after surgery compared with surgery alone for adenocarcinoma of the stomach or gastroesophageal junction. N Engl J Med. 2001; 345:725-730.

54. AJCC Cancer Staging Manual. 7 ed: Springer-Verlag New York; 2010.

55. Min BH, Tae CH, Ahn SM, Kang SY, Woo SY, Kim S, Kim KM. Epstein-Barr virus infection serves as an independent predictor of survival in patients with lymphoepithelioma-like gastric carcinoma. Gastric Cancer. 2016; 19:852-859.

56. Phillips T, Simmons P, Inzunza HD, Cogswell J, Novotny J, Jr, Taylor C, Zhang X. Development of an automated PD-L1 immunohistochemistry (IHC) assay for non-small cell lung cancer. Appl Immunohistochem Mol Morphol. 2015; 23:541-549.

57. Herbst RS, Soria JC, Kowanetz M, Fine GD, Hamid O, Gordon MS, Sosman JA, McDermott DF, Powderly JD, Gettinger SN, Kohrt HE, Horn L, Lawrence DP, et al. Predictive correlates of response to the anti-PD-L1 antibody MPDL3280A in cancer patients. Nature. 2014; 515:563-567. 